\title{
THE SACRAL STAMP OF GREEK: PERIPHRASTIC CONSTRUCTIONS IN NEW TESTAMENT TRANSLATIONS OF LATIN, GOTHIC, AND OLD CHURCH SLAVONIC
}

\author{
BRIDGET DRINKA \\ University of Texas at San Antonio
}

\section{[1] INTRODUCTION}

Among the sociolinguistic forces at work in the languages of the world, religious affiliation and the accompanying reverence for the symbols of that affiliation must rank among the most powerful. Religious texts serve as repositories of cultural tradition and become, for their followers, reliquaries of the very word of God. Besides the conservatizing, archaizing pressures which often grow up within a religious tradition, these texts also act as conduits for cultural and linguistic innovation as they spread, through transmission and translation, to surrounding populations. The New Testament (NT) represents just such a cultural conduit, providing not only a blueprint for Christian social behavior but also a pattern for Christian linguistic expression, providing a new lexicon, a special syntax, a style of its own, simple and spare. It was this style, these lexical and syntactic patterns, which came to be imbued with social value to connote membership in the Christian community, and which came to be imitated, sometimes subtly, sometimes blatantly, by translators of the New Testament.

This paper explores the role that this reverence for the Sacred Word has played in the development and spread of syntactic and stylistic patterns of the New Testament, in particular the periphrastic progressive and perfect constructions. Korvn Greek provided the model which early translators of Latin, Gothic, Old Church Slavonic, and other languages aspired to emulate, creating what Psaltes (1913) termed a "sacral stamp", a linguistic emblem of membership in the Christian community. A striking example of the role of the "sacral stamp" is provided by Luisa Amenta (2003) in her examination of the modeling of the progressive periphrastics in Latin upon the patterns of Greek. She documents the abundant use of the progressive in the Greek NT itself, in the Latin Vulgate translation, and in the Christian writings which followed from these: 


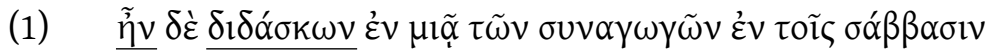

Erat autem docens in synagoga eorum sabbatis.

[LAT]

'(he) was teaching in one of the synagogues on the Sabbath' (Luke 13:10)

Amenta concludes that this structure, springing from the "lexical, syntactic, and stylistic patrimony" of the NT, had become a symbol of membership, distinguishing insiders from outsiders $(2003,17)$.

Several related questions can be posed: Do other constructions found in Latin Vulgate translations of the NT, such as periphrastic perfects and participles, bear this "sacral stamp" of Greek, similar to that described by Amenta? To what extent is this adherence to Christian, ultimately Greek, linguistic norms evident in other translations, particularly those of Gothic and Old Church Slavonic? What larger conclusions can be drawn which will help illuminate the subsequent paths these constructions took in eastern and western Europe? The data is presented here chronologically, beginning with syntactic and stylistic influences which were transmitted from Hebrew to NT Greek itself through the mediation of the Septuagint, followed by the impact that the Greek model had on translations into Latin, Gothic, and old Church Slavonic.

A preliminary holistic look at the data reveals how committed the early translators of the Bible were to the replication of the original Greek in their renditions. Evidence such as the following demonstrates an extremely close adherence to the original Greek objective complement-style perfect in the various translations: ${ }^{1}$

(2) a. 'a certain man had a fig tree planted (in his vineyard)' (Luke 13:6)

[1] The history of the Greek periphrastic perfect can be briefly summarized as follows: Classical Greek formed, alongside its synthetic perfects and periphrastic perfects in be, a periphrastic perfect with have + active aorist participle in which the participle had subject orientation:

(i)

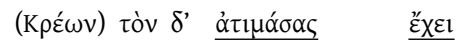

(К.)-NOM him PTC dishonored-NOM holds/has

'(K.) has treated him scornfully.' (Sophocles, Antigone 22)

By the time of the kovví, however, this construction had fallen into disuse, and had been replaced by a less grammaticalized structure with have + object + participial objective complement, as seen in this passage of Atticistic literature:

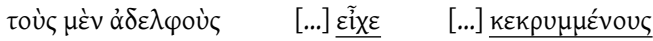

$$
\begin{aligned}
& \text { the PTC brothers-ACC.PL had/kept hidden-ACC.PL } \\
& \text { 'She kept her brothers hidden.' (Plutarch, Pelopidas 35.4) }
\end{aligned}
$$

It is this less-grammaticalized object-oriented have construction which is found in the Greek NT, and which is widely imitated in the translations to be studied here. Over time, a more grammaticalized version arose, as witnessed in the 6th c. writing of Gregory of Tours, cf. example (35) on page 54. See Aerts 1967; Drinka 2003, 2007 for further details. 


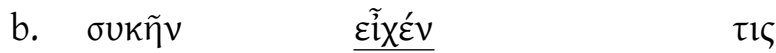

fig_tree-F.ACC.SG have-IMPERFECT.ACT.3SG someone

$\pi \varepsilon \varphi \cup \tau \varepsilon u \mu \varepsilon ́ v \eta v$

plant-PERF.PASS.PTCP.F.ACC.SG

c. arborem fici habebat quidam

tree-F.ACC.SG fig have-IMPERFECT.ACT.3Sg someone

plantatam

plant-PERF.PASS.PTCP.F.ACC.SG

d. smokovı̆nico iměaše edinŭ $[\ldots]$

fig_tree-F.ACC.sG have-IMPERFECTIVE.ACT.3sg one $\quad[. .$.

vŭsaždeno

plant-PAST.PASS.PTCP.F ACC.SG

The Vulgate of Jerome (c. 346-420 AD) follows the pattern set up in Greek strictly, and the have constructions of OCS are also translated virtually word for word, not with the expected resultative l-participle, but rather with a past passive participle, in direct imitation of the Greek original. What we will conclude is that Greek had more responsibility than is usually recognized for establishing the various patterns of periphrastic progressive and perfect use both in eastern and in western Europe.

\section{[2] THE SACRAL STAMP OF THE SEPTUAGINT ON THE EVANGELISTS}

Before assessing the role of Greek and Latin influence on syntactic and stylistic patterns in subsequent Christian writing, we must first acknowledge a remarkable fact: the Gospel of Luke and the Acts of the Apostles themselves bear a "sacral stamp." There is clear evidence that Luke consciously adopted the archaic, solemn style of the Septuagint (LXX), the literal Greek translation of the Hebrew Bible ${ }^{2}$, which gave his narrative, as Wifstrand claims $(2005,42)$, "an aura of sacred history, making it appear as the sequel and fulfillment of the Old Testament." For example, the LXX rendition of 1Samuel 2:26 clings to the Hebrew original very closely:

(3) a. wahanna'ar šəmû'ēl hōlēkè waḡādēl wātōb gam

and-youth Samuel was-growing and-stature and-favor also

'im-yəhwâ wəḡam 'im-'ănāšîm:

with-Lord and-also with-men

'Now the boy Samuel was growing in stature and in favor both with the Lord and with men.'

[HEBR]

[2] See Horrocks 1997, 57 for a discussion of the varying degrees of this literalness in the LXX: some books, such as Lamentations, are extremely literal; others, like those of the Pentateuch, use what seems to be contemporary koıvń. Esther is written in a "consciously literary" style, while 4 Maccabees is characterized as "positively Atticizing". Horrocks also observes that Hebraisms were incoporated into the Greek more often "where the obscurity or formulaic language of the original led to literalness." 


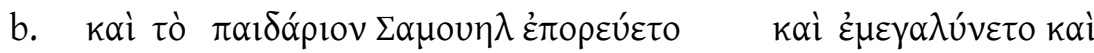
and the child Samuel was-continuing and was-growing and

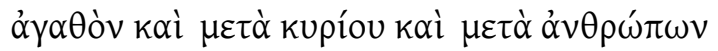
good and with Lord and with men

'Now the boy Samuel was continuing and growing in stature and in favor both with the Lord and with men' (LXX; 1Sam 2:26)

Luke fashions his description of the boy Jesus upon this passage, adopting the imperfect aspect of the verb and making abundant use of the conjunction, but formally sorting out the nouns referring to Jesus's growth from those referring to the witnesses:

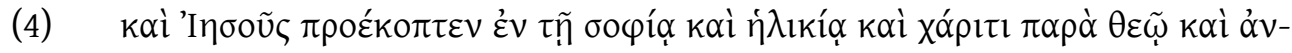

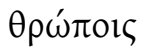

'And Jesus kept increasing in wisdom and stature, and in favor with God and men' (Luke 2:52)

Luke apparently does not rely on Hebrew directly as a model, but on the semiticized Greek of the LXX. ${ }^{3}$ He frequently employs forms which are no longer in use in the contemporary koivn but which harken back to the time of the translation of the LXX between the 3rd and 1st c. BC:

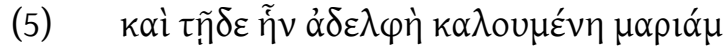

'She had a sister called Mary' (lit. 'to this one was a sister called Mary') (Luke 10:39)

According to Wifstrand $(2005,38)$, in the entire NT ö $\delta \varepsilon$ (dative $\tau \tilde{\eta} \delta \varepsilon$ ) appears as a simple demonstrative pronoun 'this one here' only in this passage and in the ancient

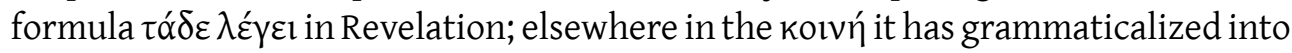
an indefinite demonstrative, 'this or that'. The archaic usage in this passage can be traced directly to LXX models like the following:

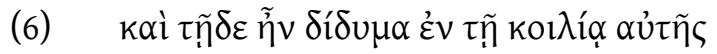

'there were twins in her womb' (lit. 'to this one were twins in her womb') (Gen 25:24)

Wifstrand $(2005,36)$ suggests that when Luke used a form which was no longer current, he may have known it from the LXX alone, such as the obsolete o $\rho \theta \rho i \zeta \omega$

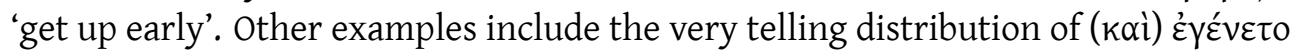
$(\delta \varepsilon)^{\prime}$ 'and it came to pass': it appears three times in Mark, six times in Matthew, but over fifty times in Luke's writing, both in the Gospel and in the Acts of the Apostles.

[3] Moulton \& Howard $(1920,480)$, however, suggest that parts of the first two chapters of Luke may have been translated directly from Hebrew. 
In the LXX, it appears hundreds of times. Unlike the other evangelists, Luke made a conscious choice to associate his narrative with the style of the LXX, which had assumed a "sacred status" among Hellenized Jews and the first Christians (Wifstrand 2005, 40-41).

With regard to the use of periphrastic constructions, specifically the progressive, the LXX provides a clear model for the construction, based upon a Semitic construction using the "waw-conversive" plus the perfective form of the verb hyy 'be'.

Ceglia $(1998,31)$ provides the following examples from Hebrew, illustrating the progressive, habitual, and ingressive uses of the periphrastic, respectively, copied exactly in the LXX: ${ }^{5}$

(7) Progressive use

[HeBR, Gк]
a. wa-yəhî
bōneh
'în
CONV-PREF-be-3sG.M construct-PART.SG.M city-SG

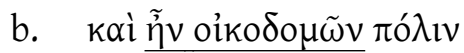 'and he was constructing a city' (LXX; Gen 4:17)

(8) Habitual use

[HeBR, GK]
a. wə-han-na'ar hāyâ məšārēț 'eț-yəhwâ and-ART-boy be-3sG.m serve-PART.ACT.SG.M ACC-God

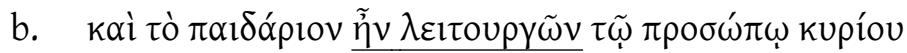 'and the boy was ministering to God' (LXX; 1Sam 2:11)

(9) Ingressive use

[HeBR, Gк]
a. wi-yə-hî
m-a-badîl
and-PREF-be-3sG PART-CAUS-separate-M.SG

[4] The Hebrew waw-conversive, a specialized use of the conjunction waw, reverses the aspectual reference of a verb, making perfective verbs imperfective, and imperfective verbs perfective. This usage appears frequently in biblical prose narratives where the first verb is perfective and the following verbs are imperfective but are to be construed as perfective through the operation of the conversive. When hyy 'be' in the perfective appears in this construction, it indicates durativity (Lehmann et al. 1999, 11, 145). Compare the following Hebrew passages with the LXX renditions:

(i)

a.

wayəhî šəmû'ēl ma‘ăleh hā'wōlâ

'and so it was that Samuel offered-PRFV $\rightarrow$ was offering-IMPRFV up the burnt offering' [HEBR] 'now Samuel was offering up the burnt offering'

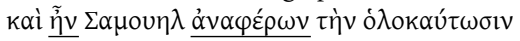

'now Samuel was offering up the burnt offering' (LXX; 1Sam 7:10)

b. wayəhî dāwi d bā' 'ad-hārō’s

'and so it was that David came-PRFV $\rightarrow$ was coming-IMPRFV to the summit'

[HEBR]

'it happened as David was coming to the summit'

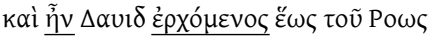

'and David was coming to the summit' (LXX; 2Sam 15:32)

[5] Ceglia's Hebrew transcription is slightly modified here, for uniformity. CONV = conversive; PREF = preformative; $\mathrm{FACT}=$ factitive. 


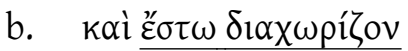 'and let it be separating [the waters from the waters]' (LXX; Gen 1:6)}

While the progressive meaning seen in (7) can be found in Greek in limited fashion as early as Herodotus, the habitual and ingressive meanings of (8) and (9) represent innovations in Greek based on the model of Hebrew, since classical Greek would have used an imperfect and an aorist, respectively, in these contexts (Ceglia 1998, 33).

The similar tendency towards verbal function of participles in the papyri and private letters also suggests the influence of Semitic, both direct and indirect, a trend which points to the pervasiveness of these structures in the Judeo-Greek Umgangssprache (Amenta 2003, 33-4; 65-6):

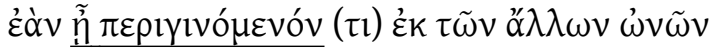

$$
\begin{aligned}
& \text { 'if (this) were being_superior among the other purchases' (Papyri Revenue } \\
& \text { Laws 19, } 8 \text { (258a)) }
\end{aligned}
$$

Luke is by far the most frequent user among the Evangelists of the periphrastic be + present participle construction for aspectual purposes (Amenta 2003,135), and he, at the same time, demonstrates the most thorough knowledge of Semitic roots. ${ }^{6}$ It seems likely, then, that Luke's frequent use of periphrasis may represent an additional attempt, like those mentioned above, to bring a stylistic feature of the LXX into his Greek.

While the periphrastic progressive is fairly well represented, the periphrastic perfect does not find its predecessor in the Semiticized Greek of the LXX. A close examination of all verbs in 1Samuel, for example, yielded no trace of this construction. What did, instead, emerge from 1 Samuel as the means of expressing the anterior ${ }^{7}$ was the synthetic aorist, as exemplified in the lyrical prayer of Hannah, mother of Samuel, as she places her son in the service of the Lord in the temple (1Samuel 2: 1-10):

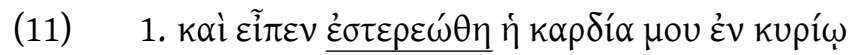

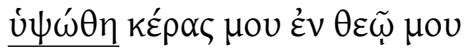

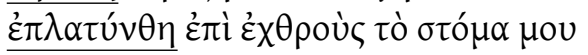

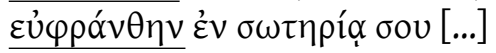

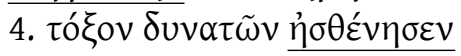

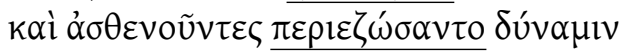

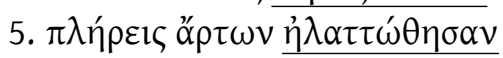

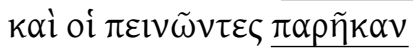

[6] As Wifstrand notes $(2005,29)$, "it is remarkable that Luke, the evangelist most steeped in Greek culture and even eager to display it, is at the same time the most flagrant Semitiser among them."

[7] The term "anterior" refers to an action or state which began in the past but which is still relevant in the present. 


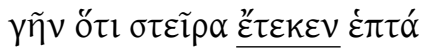

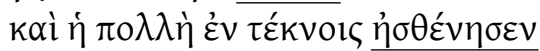

1.Then [Hannah] said "My heart has been fortified (exults) (AOR.PAss.3sG) in the Lord;

My horn (strength) has been exalted (AOR.PASs.3SG) in the Lord,

My mouth has been enlarged (speaks boldly)(Aor.PAss.3sG) against my enemies,

(Because) I have been gladdened (rejoiced) (AOR.PAss.1SG) in Your salvation. [...]

4. The bow of the mighty has weakened (AOR.ACT.3SG),

But those weakened have girded on (AOR.MID.3PL) strength.

5. Those who were full have been hired out (AOR.PASs.3PL) for bread,

But those who were hungry have ceased (AOR.ACT.3PL) [to hunger].

Even the barren has given birth (AOR.ACT.3SG) to seven,

But she who has many children has languished (AOR.ACT.3SG)."

(1Sam 2:1-5)

Remarkably, the same tenor and lyrical style-and the same verb tense-is used by Mary, mother of Jesus, in the prayer that mirrors that of Hannah, the Magnificat (Luke 1:46-55). Mary, like Hannah, uses aorists to extol the Lord for all he has done ${ }^{8}$ :

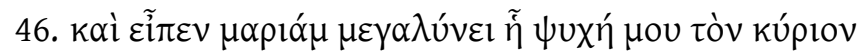

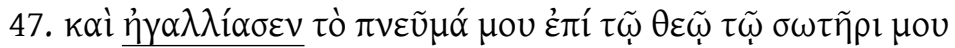

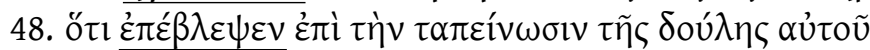

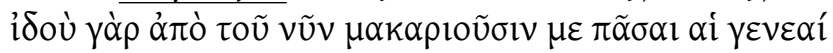

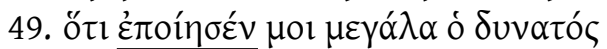

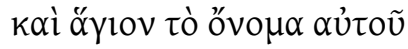

46. And Mary said: "My soul exalts the Lord,"

47. And my spirit has rejoiced (AOR.ACT.3sG) in God my Savior.

48. For he has had regard (AOR.ACT.3sG) for the humble state of his servant; For behold, from this time on all generations will call me blessed.

49. For the Mighty One has done (AOR.ACT.3SG) great things for me;

And holy is his name." (Luke 1:46-49)

Thus, while the periphrastic perfect, found in most modern European translations of these prayers and represented here in the English translation, is not yet in evidence, the sacral stamp of the LXX is still clearly to be seen.

[8] The extent to which the LXX and, ultimately, Luke replicate the syntax of Hebrew is also clearly visible in this series of verb-initial clauses, reflecting the normal Verb-Subject-Object order of Hebrew.

[9] Note that English, too, partakes of the "sacral stamp", in elevating these familiar lines by means of archaic language, such as that found in the King James version: "My soul doth magnify the Lord/And my spirit hath rejoiced in God my Saviour." 


\section{[3] THE SACRAL STAMP OF GREEK ON LATIN}

As mentioned above, the be + present participle construction was pervasive in the NT; it was, in fact, within the NT that the frequency of the construction increased significantly (Amenta 2003, 64): ${ }^{10}$

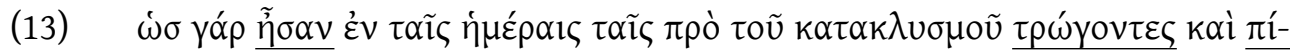

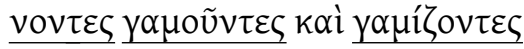

'For as in those days before the flood they were eating and drinking, marrying and giving in marriage' (Matthew 24:38)

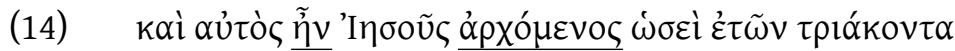

'and Jesus was beginning at about thirty years' (Luke 3:23)

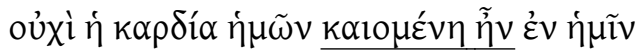

'were not our hearts burning within us' (Luke 24:32)

As also noted above, the semantic range of this construction was broader than that found in classical Greek, since it could now refer not only to progressivity and durativity, but also to ingressiveness as in $(14)^{11}$ and to imperfectivity, a function previously reserved for the synthetic imperfect alone (Amenta 2003, 74; 110).

Granted that the be + present participle construction had taken on special social value in Greek, to what extent can the perfect periphrasis likewise be seen as connoting membership? Unlike the rather abundant progressives, the have periphrastic perfects constitute a fairly small category in the New Testament, with only 16 tokens, but when the 13 periphrastic perfects formed with be + active perfect participle are added to these, the category emerges as somewhat substantial. While in Classical Greek, there is evidence of a more grammaticalized have perfect + active aorist participle (cf. ftnote 1 and Drinka 2003), in the NT the perfect is limited to the less fully grammaticalized objective complement variety (cf. Aerts 1967), where have retains its possessive value, and the participle is object-oriented: ${ }^{12}$

[10] Note the similarity of (13) to 1Samuel 30:16:

(i) a. wəhinnēh nəțušîm 'al-pənê knāl-hā'āreș 'ōkૂəlîm wəšōtî̀m wəhōōaḡîm

'and, behold, they [were] spread[ADJ] over the face of all the earth, eating and drinking and celebrating'

[HEBR]

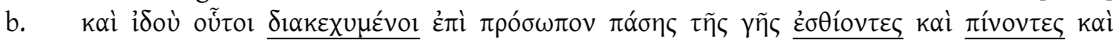

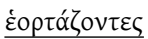

'and, behold, they [were] spread over the face of all the earth, eating and drinking and celebrating' (LXX)

Rather uncharacteristically, Luke does not replicate the periphrastic progressive in his version of this story

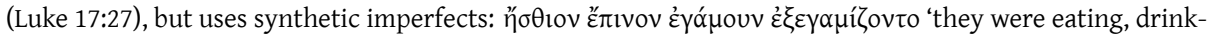
ing, marrying, being given in marriage'.

[11] Amenta $(2003,110)$ identifies this innovative usage aptly as "durativization".

[12] A fully grammaticalized perfect, such as that found in most modern western European languages, would include a completely auxiliated have and a subject-oriented participle: "Have you hardened your heart?";

"A certain man had planted a fig tree". 


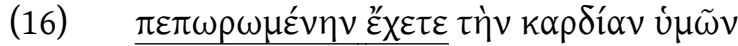

'Have you still your heart hardened?' (Mark 8:17)

(17) (=) (2) б

'a certain man had a fig tree planted' (Luke 13:6)

The most common form of the participle for the Greek have construction is the perfect passive participle ${ }^{13}$, as illustrated in (16) and (17); this participle also frequently occurs in the be periphrastic perfects, as in (18):

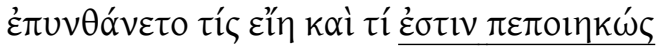

'[the tribune] demanded who he was, and what he had done' (Acts 21:33)

Thus, while the category is small, it merits our attention, especially since it represents a companion periphrastic construction to the more robust periphrastic progressive category.

Turning to the role that Greek played in shaping Latin verbal periphrasis in NT translations, we note, as mentioned above, that the Vulgate of Jerome closely follows the periphrastic progressive pattern of NT Greek: ${ }^{14}$

$(=(13))$

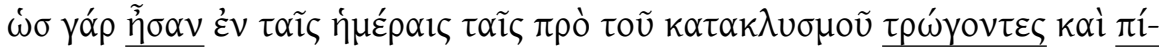

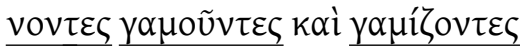

sicut enim erant in diebus ante diluvium comedentes et bibentes, nubentes et nuptum tradentes

[LAT]

'For as in those days before the flood they were eating and drinking, marrying and giving in marriage' (Matthew 24:38)

(20) $\quad(=(14))$

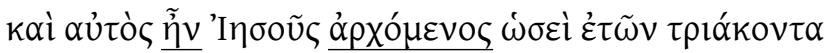

Et ipse Jesus erat incipiens quasi annorum triginta

[LAT $]$

'and Jesus was beginning at about thirty years' (Luke 3:23)

[13] The other much less frequently-attested participle type used in the Greek have construction is the present mediopassive participle.

[14] It should be noted that Jerome's task was not to create a new translation of the Greek NT, but to correct the inaccuracies in earlier Old Latin translations by comparing them to the Greek. Jerome did not coin new words, and often kept expressions from the Old Latin versions which closely, if not perfectly, approximated the Greek (Metzger 1977, 354). It appears that Jerome was more fastidious in his revisions in earlier work than later, frequently replacing participials for Old Latin finite verbs in Matthew, for example, in imitation of Greek, but doing so less frequently in later work (Metzger 1977, 353). It should also be noted that controversy exists around Jerome's role in the translation of the NT beyond the Gospels: it is possible that another translator working in Rome before 390 was responsible for translating the rest of the NT (Loewe 1969, 108). 
(21)

$(=(15))$

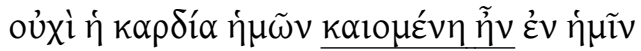

Nonne cor nostrum ardens erat in nobis

'were not our hearts burning within us' (Luke 24:32)

[LAT $]$

In these and many other examples throughout the NT, the Greek pattern is precisely replicated in the Vulgate.

With regard to the have perfects, Jerome also follows the Evangelists without fail: for each of the 16 Greek examples of the objective-complement have perfect, the Vulgate copies the pattern exactly $(22=16,23=2,17)$ :

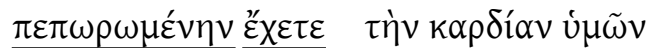

caecatum habetis cor vestrum

'Have you still your heart hardened?' (Mark 8:17) [GK, LAT]

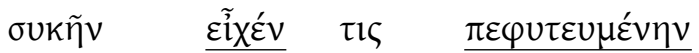

arborem fici habebat quidam plantatam

'a certain man had a fig tree planted' (Luke 13:6)

[GK, LAT]

The translation is not only literal, but syntactically identical. ${ }^{15}$

Remarkably, out of a sample of 100 examples of have in the Vulgate, only one have periphrastic was formed which did not have a Greek model. ${ }^{16}$ In contrast, the Vulgate translation conforms much less strictly to the Greek be + active perfect participle construction. In fact, most of the Latin translations of this form do not form a periphrastic in imitation of Greek, but use other constructions, such as synthetic forms:

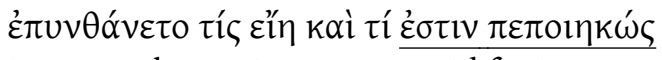

interrogabat quis esset et quid fecisset

'[the tribune] demanded who he was, and what he had done' (Acts 21:33)

[15] Note, however, the interesting lexical variation in Mark 8:17: Greek $\pi \varepsilon \pi \omega \rho \omega \mu \varepsilon ́ v \eta v$, 'petrified, hardened' vs. Vulgate caecatum 'blinded'. The form is rendered as obtusum/a + est/sunt in a number of pre-Vulgate Latin versions, but as caecatum + habetis in the Vulgate and in the Codex Brixianus (f) (Vetus, cf. Jülicher 1970, 69). The construction resembles Greek in the use of the have auxiliary, but reinterprets the meaning of the participle; in the Gothic translation, the participle shows yet another variant: daubata + habaib, lit. 'deaf, stubborn' (Lehmann 1986, 88) (cf. ex. (46) below). It may be significant that the next verse makes reference to both of these conditions: "Having eyes, do you not see? Having ears, do you not hear?" The very similar translation of Isaiah 6:10 is also telling:

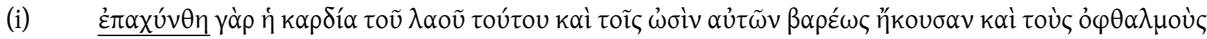

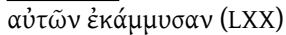

Excaeca cor populi hujus, et aures ejus aggrava, et oculos ejus claude (Vulgate)

'Make the hearts of this people insensitive, their ears dull, and their eyes dim'

[16] The original Greek expression was, in fact, a progressive periphrastic like those studied by Amenta: Gal.

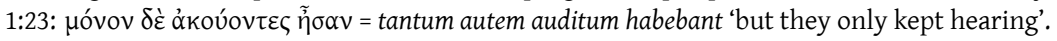


An additional intriguing fact can be mentioned here: among the ten letters of St. Jerome which I examined for this feature, there were 17 uses of have, but only one which could be considered an objective complement-type periphrastic:

(25) si hoc munusculum placuerit, habemus etiam alia condita, quae cum plurimis orientalibus mercibus ad te, si spiritus sanctus adflaverit, navigabunt. 'If my little gift should please you, we have others also stored up which (if the Holy Spirit shall breathe favorably), shall sail across the sea to you with all kinds of eastern merchandise.' (Jerome, Ad Paulum senem Concordiae, §3)

Jerome, then, as a rule, is not using the same style in his letters that he does in his Bible translations. Remarkably, this very passage, read in the context of the entire letter, gives us a clue as to why this dissimilarity in style exists. The letter, dated $374 \mathrm{AD}$, is written to the elderly owner of a theological library, asking for some commentaries and informing him that a copy of Jerome's recently completed life of Paul the Hermit was being sent to him.

(26) in quo propter simpliciores quosque multum in dejiciendo sermone laboravimus. Sed nescio quomodo, etiam si aqua plena sit, tamen eumdem odorem lagena servat, quo dum rudis esset, imbuta est.

'I have taken great pains to bring my language down to the level of the simpler sort. But, somehow or other, though you fill it with water, the jar retains the odor which it acquired when first used.' (Jerome, Ad Paulum senem Concordiae, \$3)

The style of the entire letter is notably learned and even, perhaps, haughty. Even while capable of bringing his language "down to the level of the simpler sort," Jerome clearly enjoys demonstrating his abilities to argue in the high style of a skilled rhetorician. What we can grasp from this fact is that the style that Jerome uses in his translations is an acquired style, purposefully assumed to replicate the tenor, the voice of the evangelists. And that voice, that style was Greek in its essence, whether comprised of well-endowed categories like the progressive, or less frequently used ones, like the perfect.

In another letter, this one to Pammachus (Epist. 57), dated 395, Jerome articulately defends his style of translation, ${ }^{17}$ criticized by some for its non-literalness, all while confirming his reverence for the sacred status of scriptural syntax:

[17] Cf., e.g., Jerome's graceful description of the challenges of translation, as he refers to his own introduction to his translation of Eusebius of Cæsarea: "It is hard to preserve in a translation the charm of expressions which in another language are most felicitous. Each particular word conveys a meaning of its own, and possibly I have no equivalent by which to render it, and if I make a circuit to reach my goal, I have to go many miles to cover a short distance." (Epistola LVII, \$5) 
(27) Ego enim non solum fateor, sed libera voce profiteor me in interpretatione Graecorum, absque scripturis sanctis, ubi et verborum ordo mysterium est, non verbum e verbo, sed sensum exprimere de sensu.

'For I myself not only admit but freely proclaim that in translating from the Greek, except in the case of the holy scriptures where the very order of the words is a mystery, I render sense for sense and not word for word.' (Jerome, Ad Pammachium de optimo genere interpretandi [Epistola LVII, §5])

Jerome, then, is committed to preserving, within his translation, the sacrality, the "mystery", which is resident not just in the words themselves, but within the "very order of those words". ${ }^{18}$

Christian writers who wrote in Latin before the translation of the Vulgate likewise show, in resemblance to their Greek scriptural predecessors, many be progressives and a few have perfects. Bishop Lucifer of Cagliari (4th c. AD), in his diatribe against the Emperor Constantus and his Arian heresy, denounces overly elaborate language, and speaks in favor of simple speech:

(28) noster sermo est communis contra uester politus ornatus

'our speech is common; on the other hand, yours [is] refined, ornate' (Luciferi Calaritani, Moriundum esse pro Dei Filio, lines 755-61)

Lucifer produces a number of periphrastic progressives (cf. Amenta 2003 for numerous examples):

(29) quia post tantum facinus perpetratum sis uiuens hactenus ut uixerit Saul 'so that after such a crime committed, you are living thus far as Saul lived' (Luciferi Calaritani, De regibus apostaticis 2:210)

(30) Non est, inquam, nouum, si tu in hac pertinacia sis perstans

'It is not, I say, new if you are persisting in this obstinacy' (Luciferi Calaritani, De regibus apostaticis 5:375)

Lucifer uses numerous participles, as well as the verb habeo, and an occasional instance of the joining of the two into an objective complement-style have periphrastic:

(31) peritus habeasque dictatorum designatum numerum

'(you yourself) an expert and also having a group of secretaries so designated' (Luciferi Calaritani, Moriundum esse pro Dei Filio, lines 747-8)

In contrast, examining the language of contemporary works which did not spring from the Christian tradition, we have the opportunity to determine the extent to which Christianity did or did not have an effect on the language. The Mulomedicina

[18] Sutcliffe $(1969,96)$, however, questions this translation of the term ordo verborum, suggesting, instead, 'the precise character of the words', based on Jerome's usage of this term elsewhere. 
Chironis, which probably dates to the 4th c. AD (Herman 1997, 23), is a technical text which lies outside the Christian tradition. While many present participles exist in this text, they are used adjectivally, not as part of the periphrastic verbal construction, as witnessed by the wide separation between the be verb and the participle in the following example:

sunt enim venae a visceribus descendentes

'they are, in fact, veins descending from the intestines' (Mulomedicina Chironis, Liber I:IX:26)

In the sections of the Mulomedicina which I examined for perfect constructions (427-454), there were no have auxiliaries, and, in fact, very few instances of habeo at all (all non-grammaticalized, such as si vermes habeat... 'if he has worms...'); there was, in addition, an apparent preference for infinitives to participles. The language is noun-heavy, and simple in construction, as is suitable for its practical purpose. It is evident that this text is written in a different style from that of the NT, and relies on different linguistic traditions.

Two additional works, Romana and Getica, both written by Jordanes in the 6th c. $A D$, also provide valuable evidence of Latin writing within the Greek tradition but outside of the Christian tradition. Remarkably, these works provide no examples at all of the periphrastic progressive, either adjectival or aspectual (Amenta 2003, 106), and among the 12 examples of habeo in the Romana and 52 examples in the Getica, only one possible example of a periphrastic perfect exists:

(33) Quam adversam eius valitudinem captans Balamber rex Hunnorum in Ostrogotharum parte movit procinctum, a quorum societate iam Vesegothae quadam inter se intentione seiuncti habebantur ${ }_{\text {[3pl. pass. imperf] }}$

'Balamber, king of the Huns, took advantage of his ill health to move a force into the land of the Ostrogoths, from whom the Visigoths were already held separated because of some dispute.' (Getica XXIV 130)

The passive character of habebantur suggests that the form must be interpreted as 'hold', rather than as a more grammaticalized have auxiliary.

Within the Christian tradition of the 6th c. A.D., by contrast, further grammaticalization has occurred in both the progressive and the perfect periphrastics, as seen in the writing of Gregory of Tours:

(34) erat regnum cum iustitia regens, sacerdotes venerans, ecclesias munerans, pauperes relevans et multis multa beneficia accommodans

'he was ruling the kingdom with justice, honoring priests, funding churches, comforting the poor, and providing various benefits to many' (Greg. Tur. His. Franc. 3, 25) 
Among the perfects, we note fuller auxiliation of have and more complete subjectorientation of the participle, resulting in what can be considered a precursor to the have perfects found across western Europe in the ensuing centuries:

episcopum...invitatum habes

'you have invited the bishop' (Greg. Tur. Vit patr. 3,1)

In sum, Greek has provided a powerful model, leaving its mark most directly on Jerome's translations, but also upon the writings of later Christian writers, as well. The virtual lack of the periphrastic progressive and the scarce evidence for the periphrastic perfect in writings by authors outside the Christian tradition points to a connotation of membership that these structures, especially the progressive periphrasis, conveyed.

\section{[4] THE SACRAL STAMP OF GREEK AND LATIN ON GOTHIC}

In the 4th century, Wulfila, who was probably the son of a Cappadocian mother and a Gothic father, translated the Bible into Gothic. His Arian theological stance is not very visible, except perhaps in the translation of one telling phrase from the original Greek (Metzger 1977, 377): while Greek and Latin characterize Christ as one "equal with God", Wulfila restates this characterization as "being like God":

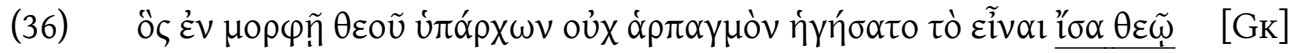
saei in gudaskaunein wisands ni wulwa rahnida wisan sik galeiko guda [Codex Ambrosianus B]

[GoTH] qui cum in forma Dei esset, non rapinam arbitratus est esse se æqualem Deo

"who, although he existed in the form of God, did not regard being equal with God (being like God) a thing to be grasped' (Philippians 2:6)

The largest accumulation of surviving Gothic texts actually do not come from the Balkans where Wulfila wrote, but from Northern Italy, where the Ostrogothic chieftain, Theodoric, had invaded and where a scribal tradition fostered by the ruling Goths grew up in the fifth and sixth centuries (Metzger 1977, 377). The paleographic evidence points to the unified nature of this effort, and to the wealth of material resources invested in its production: five of the surviving eight documents were written on purple parchment in silver and some gold ink. Only the splendid Codex Argenteus (CA) and one other leaf found in Egypt (Fragmentum Got. Giessenense) survived the scraping off of the precious ink and the recycling of the valuable parchment as palimpsests (Metzger 1977, 377-81). ${ }^{19}$

[19] See Metzger 1977, 378-80 for a complete account of the "romantic" and remarkable history of the Codex Argenteus. The four Codices Ambrosiani ([A], [B], [C]. and [D], all palimpsests) were found in Milan at the Ambrosian Library, but may have been rewritten at Bobbio (Metzger 1977, 381). 
Wulfila's translation tends to replicate the structures and lexicon of the Greek very precisely. As Friedrichsen states, the fundamental principle followed in Wulfila's translation is that every word is translated, in the same order:

No other feature of the Gothic Version is more characteristic of the translator's style than this. Every word of the Greek text, excepting the definite article, is normally represented in the Gothic, even particles like $\mu \varepsilon \varepsilon^{\prime}, \delta \delta^{\prime}, \alpha^{\prime \prime} v$, and others (Friedrichsen 1926, 15)

The following example provides an illustration of how faithful Gothic is to the Greek model in the translation of participles and other structures:

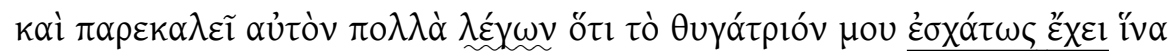

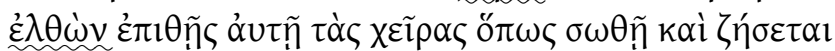
jah bap ina filu, qibands patei dauhtar meina aftumist habaip, ei gimands lagjais ana bo handuns, ei ganisai jah libai. [CA]

[GOTH] et deprecabatur eum multum, dicens: Quoniam filia mea in extremis est, veni, impone manum super eam, ut salva sit, et vivat. [LAT] :....and implored him earnestly, saying, "My little daughter is at the point of death; coming/come, lay Your hands on her, so that she will get well and live."' (Mark 5:23)

In this passage, the Gothic rendition resembles Greek more fully than the Latin

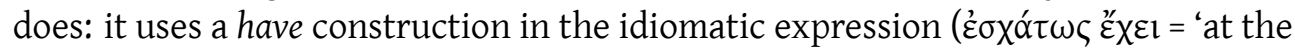
last point, extreme' [adv.]), precisely as Greek does, while Latin uses be instead (cf. the underlined forms vs. the double-underlined forms); Gothic copies both participles, 'saying' and 'coming' (wavey underline), but Latin uses the finite imperative 'come' (dotted underline); both Gothic and Latin copy the marked syntax of the Greek in saying, literally, "and he exhorted him much, saying that: '...”. It is clear, then, that Greek played an essential role in providing a model for Gothic syntactic and stylistic patterns.

It should be noted, however, that, while the influence of Greek is pervasive, the Gothic text does still retain a number of essential Germanic features such as inflections and some temporal-aspectual distinctions. Aspect or Aktionsart was apparently marked somewhat independently from Greek, based more on the exigencies of the context than on the Greek model. For example, in the following passage, Greek uses ákoúøn, an aorist active subjunctive 3sg, but Gothic does not follow suit with a perfective ga-form or a compound:

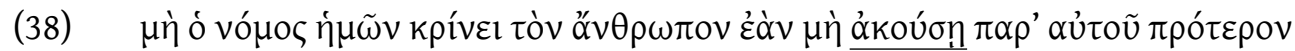

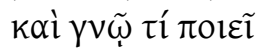
ibai witop unsar stojip mannan, nibai faurpis hauseip fram imma jah ufkunnaip hva taujai? [CA] 
Numquid lex nostra judicat hominem, nisi prius audierit ab ipso, et cognoverit quid faciat?

[LAT] 'Our Law does not judge a man unless it first hears from him and knows what he is doing, does it?' (John 7:51)

Gothic does not copy Greek's subtle use of aspectual nuance here: the perfective meaning of "hears purposely, listens to" in Greek appears not to be attended to in Gothic. Conversely, Gothic may use an aspectually charged ga-prefix without the model of an aorist or other perfective usage in Greek: ${ }^{20}$

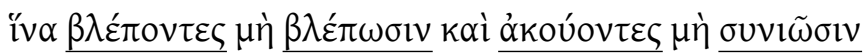
[GK] ei saihvandans ni gasaihvaina, jah gahausjandans ni frapjaina [CA] [Gотн] ut videntes non videant, et audientes non intelligent [LAT] 'so that seeing they may not see, and hearing they may not understand' (Luke 8:10)

In the first half of the sentence, Gothic replicates the use of the subjunctive in Greek by means of the optative, but sets up an aspectual contrast not present in the Greek: 'in carrying out the act of seeing, they may not accomplish the act of seeing.' The prefixed present participle gahausjandans, likewise, implies perfectivity not seen in the Greek. ${ }^{21}$

Similarly, Gothic shows some tense distinctions at variance with Greek. As Klein notes $(1992,368)$, Gothic translates an aorist as a present in the Magnificat: ${ }^{22}$

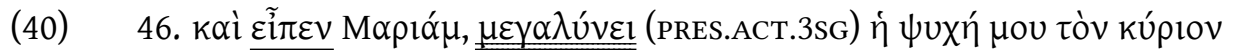
jah qap Mariam: mikileid (PRES.ACT.3sG) saiwala meina fraujan 'And Mary said: "My soul exalts the Lord,

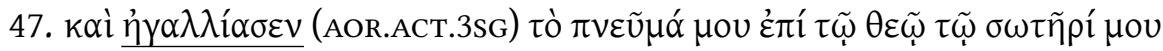
jah swegneid (PRES.ACT.3SG) ahma meins du guda nasjand meinamma. And my spirit has rejoiced/rejoices in God my Savior.

[20] See Scherer 1954, Krause 1968, 213-15, Lloyd 1979, Lehmann 1986, 133 for a discussion of various views on the aspectual value of the Gothic prefix ga-.

[21] The LXX rendition of Isaiah 6:9 upon which this verse is based copies the Hebrew exactly, and sets up more structural parallelism than Luke's refashioning, relying on the Aktionsart distinction in the lexemes $\beta \lambda \varepsilon \dot{\pi} \pi \omega$ 'look' and ópów 'see' (with a suppletive aorist) to construct the contrast:

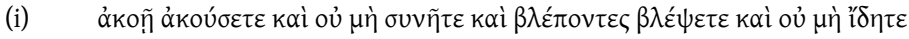

'with hearing you will hear, but you will not understand; looking you will look, but you will not see'

Both $\sigma u v \tilde{\eta} \tau \varepsilon$ and 'i $\delta \eta \tau \varepsilon$ are $2 \mathrm{pl}$ aorist active subjunctives; used with two negative particles (oủ $\mu \grave{)}$ ), they imply emphatic negation, so that a more accurate translation would be 'hearing you will hear; there is no way that you will understand; looking you will look; there is no possibility that you will see'. The passage from Isaiah is quoted exactly in Matthew 13:14 and Acts 28:26, but, unfortunately, the Gothic translation is not extant for any of these verses.

[22] The present tense is marked with a double underline, the aorist/past with a single underline. 


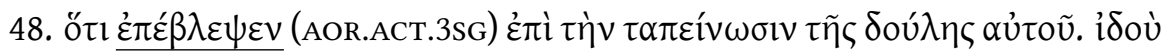

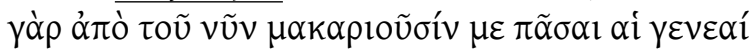

unte insahv (РAST.ACT.3SG) du hnaiweinai piujos seinaizos; sai allis, fram himma nu audagjand mik alla kunja.

For he has had/had regard for the humble state of his servant; For behold, from this time on all generations will call me blessed.

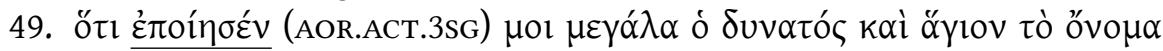

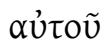

unte gatawida (РAST.ACT.3SG) mis mikilein sa mahteiga, jah weih namo is.

For the Mighty One has done/did great things for me; and holy is his name."' (Luke 1:46-49)

As can be seen in these verses, Wulfila tends to follow Luke in translating presents as presents and aorists as perfective preterites, but he does not do so in verse 47, where

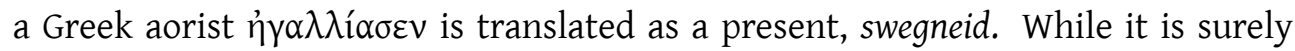
true, as Klein points out $(1992,368)$, that the preterite would not as successfully convey the immediacy of Mary's joy as the present does, it must also be noted that preterites are used in the following two lines to render aorists. Furthermore, aorists in the kolvn frequently expressed anterior meaning at this time as perfects and aorists began to fall together (Horrocks 1997, 118), so that a present translation, while rare, would not be entirely unlicensed. In the last analysis, it seems best to recognize, with Klein, that some variability in the temporal-aspectual system did exist in the Gothic version, but that imitation of Greek syntactic patterns was far more common.

As noted with regard to the synthetic aorists, Gothic tends to follow Greek consistently in rendering the synthetic perfects of Greek as perfective preterites, as well (Krause 1968, 216):

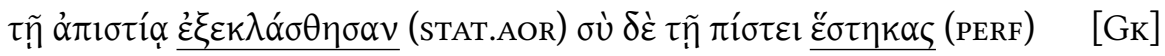

$$
\begin{aligned}
& \text { Ungalaubeinai usbriknodedun, ip pu galaubeinai gastost [A] } \\
& \text { propter incredulitatem fracti sunt. Tu autem fide stas }
\end{aligned}
$$

As concerns the translation specifically of the periphrastic progressives and perfects in Gothic, we find, once again, very frequent use of the progressive in imitation of the Greek, and careful modeling of the objective complement-style perfect, as well. Evidence for the pervasiveness of the progressive is provided by abundant examples of be + present participle: 


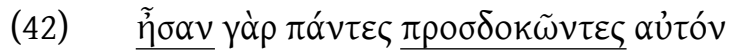

wesun auk allai beidandans is [CA]

erant enim omnes exspectantes eum

'for they had all been waiting for him' (Luke 8:40)

These occur even with stative verbs, as (43) and (44) illustrate:

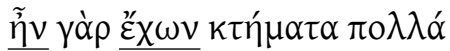

$[\mathrm{GK}]$

was auk habands faihu manag. [CA]

[GoTH]

erat enim habens multas possessiones.

[LAT]

'for he was one who owned much property' (lit. 'he was having') (Mark 10:22)

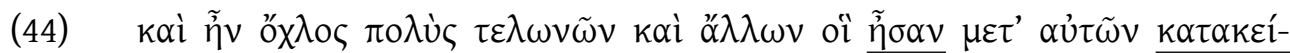
$\mu \varepsilon v o l$

jah was managei motarje mikila jah anparaize, paiei wesun mip im anakumbjandans..$^{23}[\mathrm{CA}]$

[GoTH]

et erat turba multa publicanorum, et aliorum qui cum illis erant discumbentes.

[LAT]

'and there was a great crowd of tax collectors and others who were reclining [at table] with them' (Luke 5:29)

Further evidence of the pervasive use of the progressive is even provided by the above-mentioned Gothic-Latin bilingual Bible fragment from Giessen (Fragmentum Got. Gissensis), ${ }^{24}$ for among the few fragmentary lines in the Gothic portion can be found the ending of a present participle, -ndans. Streitberg (1971, 496-8) reconstructs the line as follows:

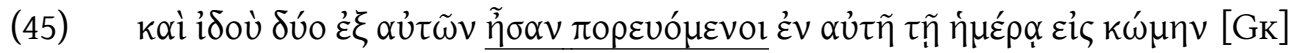
jah sai twai ize wesun gaggandans in pamma daga in haim

[GoTH] Et ecce duo ex illis ibant ipsa die in castellum

'And behold, two of them were going that very day to a village' (Luke 24:13)

[23] The Gothic participle anakumbjandans 'reclining at table' represents a remarkable example of a mixed calque, with a refashioning of the prefix, presumably *anda-, based upon Greek ó $\alpha \alpha-$ and a replication of the Latin stem in discumbentes, probably to signify a method of gathering at table which was foreign to the Goths (see Lehmann 1986, 31 for discussion and references).

[24] The double-leaf, 6th c. Fragmentum Got. Gissensis, found in Egypt, is also important for demonstrating the existence of Latin-Gothic bilingual Bibles, the other example of which is the 6th c. Wolfenbüttel palimpsest (Codex Carolinus). Friedrichsen (1926, 184 et passim) claims that the Latin Palatinian and Brixian codices, on the one hand, and the Gothic Codex Argenteus, on the other, likewise began as bilingual Bibles, a claim quickly dismissed by Burkitt (1927). While it may not be possible to view the Codex Palatinus in this precise role, it is surely the case that Gothic was influenced by Latin, and, to a lesser extent, Latin by Gothic. See Burton (2002) for an assessment of the validity of Friedrichsen's claims. 
Gothic copies the periphrastic construction, while Latin opts for a synthetic imperfect. Likewise, we find Greek objective-complement perfects well-replicated in Gothic:

(=(16), (22))

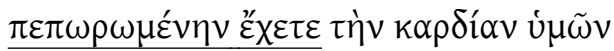

daubata habaip hairto izwar [CA]

[GK]

caecatum habetis cor vestrum

[GoTH]

'Have you still your heart hardened?'25 (Mark 8:17)

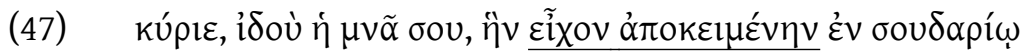

[GK]

frauja, sai, sa skatts peins panei habaida galagidana in fanin [CA] [Gотн]

Domine, ecce mna tua, quam habui repositam in sudario [LAT]

'Master, here is your mina, which I kept put away in a handkerchief' (Luke 19:20)

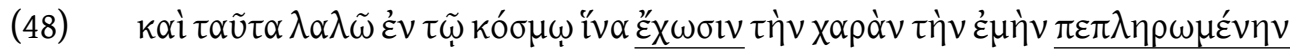

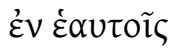

$[\mathrm{GK}]$ jah pata rodja in manasedai, ei habaina fahed meina usfullida in sis. [CA]

[GoTH]

et hæc loquor in mundo, ut habeant gaudium meum impletum in semetipsis.

'and these things I speak in the world so that they may have my joy fulfilled in themselves.' (John 17:13)

It has frequently been stated that Gothic did not have a have perfect per se: Meillet $(1970,70)$ suggests that this lack of a periphrastic perfect implies that the Germanic languages developed their have perfects late, based on the influence of Vulgar Latin. ${ }^{26}$ Benveniste $(1971,178-9)$, on the other hand, rejects the role of Latin, and claims that the "structural conditions for this innovation were present in Germanic"; he predicts that Gothic would probably have eventually developed a have perfect on its own. ${ }^{27}$ Several remarks are in order here. First of all, it is not quite accurate to say that no have perfect exists in Gothic at all. As we have seen illustrated above, Gothic copies the objective-complement-style have perfect precisely from NT Greek. What can be said with more precision is that Gothic shows no sign of independent usage of the more grammaticalized have perfect: every instance in Gothic of the objective complement perfect is based on a Greek exemplar.

[25] See again $\mathrm{ftnote} 15$ for a discussion of this lexical variation.

[26] "An important procedure, not yet utilized by Gothic and doubtlessly owing in the beginning to imitation of Vulgar Latin models, is that which consists of uniting the participle with the verb 'to have.' "

[27] According to Benveniste (1971, 178-9), the development of the have perfect was an "autonomous development in Germanic and owes nothing to the influence of Latin." 
There exist, however, at least two intriguing exceptions to the above statement, and these exceptions may have significant implications for our understanding of the development of the perfect in the Germanic languages, and the role that Latin played in this development. Consider the following example from 1Timothy:

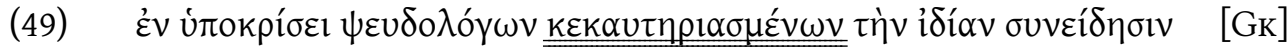
in liutein liugnawaurde jah gatandida habandane swesa mipwissein $[\mathrm{A}]$

[GoTH]

in hypocrisi loquentium mendacium, et cauteriatam habentium suam conscientiam

'by means of the hypocrisy of liars, having been seared in their own conscience (as with a branding iron)' (1Timothy 4:2)

The morphological features of the participles are as follows:

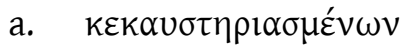
brand-GEN.PL.PERF.PASS.PTCP
'having been branded' (agrees with $\psi \varepsilon v \delta \circ \lambda{ }^{\circ} \gamma \omega v$ 'of those speaking lies')
[GK]
b. gatandida habandane
burn-ACC.SG.FEM.PAST.PTCP have-GEN.PL.PRES.PTCPLE
(gatandida agrees with mikwissein 'conscience', habandane agrees with liugnawaurde 'of those speaking lies', compound calqued on Gk. $\psi \varepsilon v \delta o-$ $\lambda o ́ \gamma \omega v)$
$\begin{array}{ll}\text { c. cauteriatam habentium } & \\ \text { brand-ACC.SG.FEM.PAST.PASS.PTCP have-GEN.PL.PRES.PTCPLE }\end{array}$
[Gотн]
(cauteriatam agrees with conscientiam 'conscience', habentium agrees with loquentium mendacium 'of those speaking lies')

What is especially noteworthy here is that Greek has provided the model of a synthetic perfect participle, but Gothic and Latin have resorted to the use of a periphrastic perfect participle, and have done so in precisely the same way; ${ }^{28}$ that is, while the Greek perfect essentially encapsulates the anterior meaning 'having been branded' in its synthetic perfect form, Latin and Gothic construct this semantic equivalence by means of a have perfect, each following exactly the same pattern. This periphrastic have perfect is not the objective complement construction seen throughout the Greek NT and thoroughly imitated by Jerome and Wulfila, but rather a more grammaticalized have perfect, similar to that found in the 6th c. writing of Gregory of Tours (cf. (35), repeated here as (51)) which resembles the later perfects of Europe:

[28] Also to be noted is the fact that both Latin and Gothic have added a conjunction 'and' in the middle of the sentence, a feature which further distinguishes them from the Greek. 
$(=(35))$

episcopum...invitatum habes

'you have invited the bishop' (Greg. Tur. Vit patr. 3,1)

Connections with the objective-complement-style perfect are still to be noted in both (49) and (51), since the participles still agree with the objects. Thus, these passages could be construed as meaning 'having their conscience seared' and 'have the bishop invited'. The fact that the perfects from Timothy replace a synthetic perfect, however, and that the auxiliary and participle are contiguous suggests that they are more grammaticalized than have constructions found elsewhere in the NT.

What could explain this exceptional use of a more grammaticalized have perfect, conforming to later, Latinate patterns rather than Greek ones? As mentioned above, the scribal tradition which fostered the greatest production of Gothic texts was located in northern Italy in the 5th and 6th centuries, and it seems clear that the influence of this western tradition is reflected here. Especially influential were two Old Latin codices referred to above, the 4th-5th c. Codex Palatinus and the 6th c. Codex Brixianus, both of which show signs of having been influenced by Gothic, as well. ${ }^{29}$ The Gothic Codex Argenteus has especially close ties to the Codex Brixianus, as witnessed not only by their identical script, but also by numerous linguistic similarities (Kauffmann 1900; Burkitt 1900; Streitberg 1971, xlii-xliv; Hunter 1969, 349). ${ }^{30}$ The Gothic Codex Ambrosianus, from which the example from Timothy is drawn, appears to have an especially strong affinity to the Latin tradition of the west (Friedrichsen 1939; Stutz 1972). In fact, it is in the letters to the Colossians, 1Timothy, and 2Timothy that the largest preponderance of Latin influences occur among the Epistles (Friedrichsen 1939, 181).

[29] The influence of Gothic on the Latin of the Palatinian version (e) can be seen, for example, in Luke 1:9:

(i)

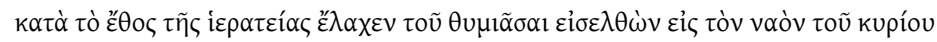
bi biuhtja gudjinassaus hlauts imma urrann du saljan, atgaggands in alh fraujins [CA] [GотH] secundum consuetudinem sacerdotii, sors (+illi $e$ ) exiit ut incensum poneret, ingressus in templum Domini

'according to the custom of the priesthood, it fell to him by lot to burn incense, entering into the temple of the Lord'

The Gothic version adds imma, 'to him' because the infinitive du saljan requires it. Since Latin uses a finite clause (ut...), it does not require the pronoun. But in the Palatinian version, an extraneous illi is added, clearly demonstrating reliance on the Gothic pattern (Friedrichsen 1926, 174). Examples of Gothic influence on the Codex Brixianus (f) include, for example, the conflation of Alexandrian $\dot{\varepsilon} \varphi \circ \beta \eta \dot{\theta} \theta \eta \sigma \alpha v$ 'they feared' with Byzantine $\dot{\varepsilon} \theta \alpha u ́ \mu \alpha \sigma \alpha v$ 'they marvelled' in Matthew 9:8, producing Gothic ohtedun sildaleikjandans 'marvelling they feared', copied in the Codex Brixianus as admirantes timuerunt but not found in any other Latin rendering (Burkitt 1900; Hunter 1969, 350).

[30] The fact that the Codex Brixianus was bound with a preface to a Gothic-Latin bilingual Bible, and that reference is made there to the wulbres, special Gothic marginal glosses, tied specifically to the CA, suggests strongly that these two works originally constituted a bilingual bible (Hunter 1969, 349). The influence of the Vulgate is also evident: according to Burkitt (1900), the Codex Brixianus resembles the Vulgate about $90 \%$. 
It may, indeed, be possible to use this small clue to draw a larger conclusion: that Wulfila followed Greek precisely in forming objective complement perfects, but that Gothic scribes of the 6th c., located in Northern Italy, were influenced by later Latin trends of their own time (Friedrichsen 1926,161), and produced a more grammaticalized, Latinized version of the perfect. The remarkable similarity of the Gothic and Latin patterns thus constitutes further evidence of Latin influence, as described above.

Similar evidence is provided by an additional verse from 2Timothy:

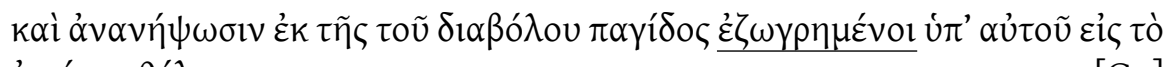

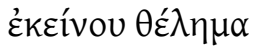
jah usskarjaindau us unhulpins wruggon, fram pammei gafahanai habanda afar is wiljin. [A]

[GoTH] jah usskarjaindau us unhulpins wruggon, fram pammei gafahanai tiuhanda afar is wiljin. [B]

[GoTH] et resipiscant a diaboli laqueis, a quo captivi tenentur ad ipsius voluntatem

'and they may come to their senses [and escape] from the snare of the devil, having been held captive by him to do his will.' (2Timothy 2:26)

Once again, Latin and the two extant versions of Gothic from Codex Ambrosianus $\mathrm{A}$ and $\mathrm{B}$ agree in constructing periphrastic replacements for the complex synthetic Greek form, the A version closely replicating the Latin captivi tenentur, though using have rather than hold as the auxiliary, the B version focusing more pointedly on the leading away of captives. ${ }^{31}$ In both cases, the Gothic is based squarely on the Latin, with the A version constructing a more grammaticalized have perfect similar to that found in example (49) from 1Timothy 4:2. ${ }^{32}$

What can we conclude from these findings? I suggest that these manuscripts are providing small but significant evidence that the absence of grammaticalized have perfects in the archaic layers of Gothic is no anomaly, as implied by Benveniste, but that this absence reflects the non-productivity of perfects in the earlier-attested Germanic languages. It is only when Gothic comes in contact with Latin that more grammaticalized western European-style have perfects develop. The data, then, support the views of Meillet, that Latin had much to do with the development of the

[31] The B variant was clearly influenced by a nearby parallel passage, 2Timothy 3:6 (Friedrichsen 1939, 250; Streitberg 1971, 436):

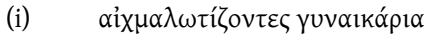


category in Germanic. Here we may be witnessing, in microcosm, how that influence occurred: Gothic tends to imitate the objective-complement style of perfects of NT Greek, but in several cases where Latin influence is clearly in evidence, the use of the have perfect resembles the more grammaticalized version. The versions of Gothic, then, may be providing evidence not only for the effect of a Greek pattern, but also, in several key examples, of a more grammaticalized Latin model.

Finally, with regard to the larger issue at hand, evidence for the "sacral stamp," this adoption of a more grammaticalized have perfect may also have been partially motivated by a desire on the part of the Latin and Gothic translators to render the aspectual nuance of the Greek participles with greater precision. The translators could simply have used past passive participles (e.g., 'burned', 'captured') but, by inserting the have, they insisted upon the anteriority of the event implied by the Greek synthetic perfect (e.g., 'having been burned', 'having been captured'). The impetus for providing a more nuanced paraphrase seems, again, to be due to a reverence for the Sacred Word.

\section{[5] THE SACRAL STAMP OF GREEK ON OLD CHURCH SLAVONIC}

The early influence of Greek is also extensive in Old Church Slavonic translations of the Bible. As Růžička $(1963,3)$ notes, OCS texts consisted almost completely of translations of Greek religious texts, and these tended to be extremely literal because of the high esteem in which the originals were held. The first Slavic literary language was thus shaped according to the syntactic patterns and stylistic norms of Greek. Hannick $(1972,424)$ and Tzitzilis $(1999,605)$ also draw attention to the influence that Greek played in the Slavic translations of the 9th-12th c.

In the 6th c., the Slavs and other nomadic tribes entered the Balkan peninsula, settling in areas which were less intensely hellenized or romanized (Schaller 1975, 61; Banfi 1985, 135; Asenova 1999, 213). OCS developed in the ambience of Greek culture and language, and, as has been seen elsewhere, contact with Greek played an essential role in the development of various participial constructions in that language. Rủžička $(1963,365)$ summarizes the role of Greek in the strongest terms:

Die Vorbildwirkung des Griechischen auf das Partizipialsystem der altslavischen Übersetzungen war von einer Stärke, die in der Geschichte großer Literatursprachen wenige Beispiele kennt. ${ }^{33}$

The Greek New Testament, along with later medieval Byzantine texts, provided OCS writers with abundant syntactic, semantic, and stylistic models of participial usages. Růžička $(1963,17)$ presents a rich array of examples of such influence, illustrating how OCS translators patterned their participle and periphrastic usage on

[33] "The role model effect of Greek on the participial system of ocs translations was of a strength which has seldom occurred in the history of the major literary languages." 
that of their Greek models. Among the numerous progressives can be listed the following:

(=(13), (19))

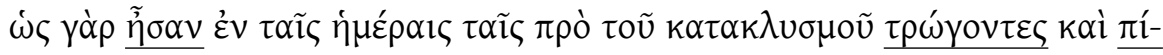

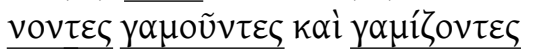

sicut enim erant in diebus ante diluvium comedentes et bibentes, nubentes et nuptum tradentes

[LAT]

ěkože bo běachǫ, vŭ dĭni prěžde potopa, ědošte i pijošte, ženęšte sę i posagajošte

[OCS]

'For as in those days before the flood they were eating and drinking, marrying and giving in marriage' (Matthew 24:38)

(54) (=(42))

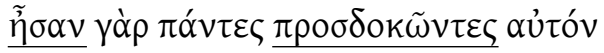

$[\mathrm{GK}]$

wesun auk allai beidandans is [CA]

[GoTH]

erant enim omnes exspectantes eum

[LAT]

běachǫ bo vǐsi čajǫšte ego

'for they had all been waiting for him' (Luke 8:40)

[OCS]

(55) $\quad(=(15),(21))$

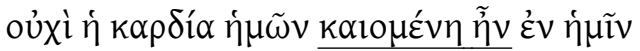

[GK]

Nonne cor nostrum ardens erat in nobis

ne srdce li naju gorę bě vŭ naju

[OCS]

'were not our hearts burning within us' (Luke 24:32)

The syntactic parallelism across languages is unmistakable: in each example, the components of the progressive construction are placed in exactly the same position. Růžička $(1963,204)$ points to a morphosyntactic differentiation not evident in the Greek which is, however, found in the distribution of the auxiliary in OCS: běacho functions as a full verb and can be separated from the participle, while bé, being fully grammaticalized, has no independent semantic value and is not separable. ${ }^{34}$ This tendency is to be noted in most cases, as illustrated above, but exceptions exist:

$(=(14),(20))$

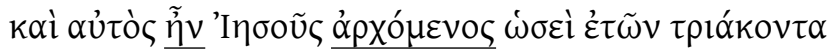

jah silba was Iesus swe jere prije tigiwe uf gakunpai ${ }^{35}$ [CA]

[34] The auxiliary byti is, however, not grammaticalized to the point of being deletable, as the copula is. Rǔžička goes on to identify the bě form as an "intensive imperfect" (Růžička 1963, 202-3; 216).

[35] The challenge of interpreting the Greek also causes difficulty in Gothic, where uf gakunpai translates ápxó $\mu \varepsilon v o \zeta$ in an unclear way, perhaps meaning 'under obedience' (Streitberg 1971, 99). 
Et ipse Jesus erat incipiens quasi annorum triginta

itŭ bě isŭ. ěko trĭmi desęty lětŭ. načinaję.

[OCS]

'and Jesus was beginning at about thirty years' (Luke 3:23)

Růžička $(1963,173-4)$ explains that the participle načinaję here formally modifies the validity of the entire predication bě trĭmi desęty lětŭ 'he was thirty years old', making be the preferable choice.

A similar faithfulness to the Greek model is to be found in the construction of the be perfects, as witnessed even by the use of the že particle in imitation of the Greek $\delta \dot{\varepsilon}$ as in the following example of a pluperfect:

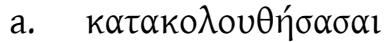
$\delta \grave{\varepsilon} \quad \alpha \dot{\imath}$
follow_after-AOR.ACT.PTCP.F.NOM.PL PTCL DEF.ART.F.NOM.PL

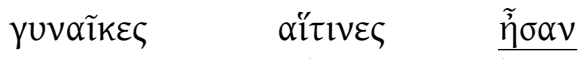
woman-F.NOM.PL who-F.NOM.PL be-IMPERFECT.ACT.3PL

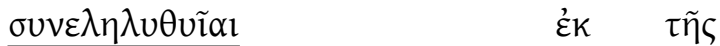
come_with-PERF.ACT.PTCP.F.NOM.PL out_of DEF.ART-F.GEN.SG
$\Gamma \alpha \lambda_{\imath} \lambda \alpha \operatorname{li}_{\alpha \varsigma} \quad \alpha \dot{\tau} \tau \tilde{\omega}$
Galilee-F.GEN.SG him-DAT.SG
b. vŭ slědŭ že šĭdǔšę
in tracks PTCL follow-IMPERFECTIVE.ACT.PTCP.F.NOM.PL

ženy, jęže běacho sŭ nimŭ

woman-F.NOM.PL who-F.NOM.PL be-IMPERFECT.ACT.3PL with him

prišily ot galileję

come-PAST.ACT.PTCP.PL from Galilee

'Following after, the women who had come with him from Galilee...' (Luke 23:55)

The OCS translator copies both the initial aorist participle construction to describe the women who were following and the Greek pluperfect construction in be + perfect active participle ( $\tilde{\eta} \sigma \alpha v \sigma u v \varepsilon \lambda \eta \lambda u \theta v \tilde{i} \alpha$ ) by using the imperfect form of be + past active l-participle (běacho prišily). It is clear that both participial formations illustrated here conform precisely to that of the Greek original. ${ }^{36}$ By contrast, the Latin rendition of the be perfect, as mentioned above, does not construct a pe-

[36] Rǔžička does not focus on the role of the l-perfect in his book, nor on periphrastic perfects in general; he excludes the $l$-perfects from consideration because they constitute "eine einheitliche und syntaktisch wenig problematische Verwendung im Altslavischen" ("a uniform and not very problematic use, syntactically, in OCS") (Růžička 1963, vi). That the unified nature of this perfect is due to its antiquity is confirmed by Meillet $(1922,42)$, who notes that the $l$-perfect surely dates back to Proto-Slavic, although it represents an innovation from an Indo-European standpoint (pace Večerka $(1993,88)$, who regards the replacement of the synthetic IE perfect with the l-perfect as occurring in dialectal Indo-European). Trost (1972, 93-99) illustrates the flexibility which OCS translators demonstrate in their rendering of subtle semantic distinctions of the Greek models in their l-perfect constructions. 
riphrastic perfect, but uses a synthetic pluperfect, venerant: ${ }^{37}$

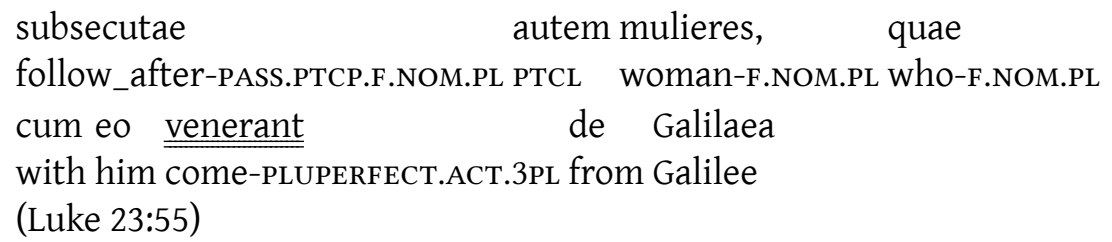

The introductory participle is also noteworthy: while Greek and Old Church Slavonic have past active participles at their disposal, Latin has only the perfect deponent participle, identical in form to the perfect passive participle, to connote both pastness and activeness at once. As a deponent verb, then, subsecutae accurately replicates the aorist active participle of Greek. However, if a transitive verb had been used, such a precise replication could not have occurred, since the perfect participles of transitive verbs in Latin are passive. The limited range of participles in Latin in comparison with those of Greek and OCS may have larger than expected implications: the preference for be perfects in the East and their more attenuated use in the West may be connected to divergent tendencies already visible in OCS and Vulgar Latin. ${ }^{38}$

The identification of OCS preterite participles with Greek aorist and perfect participles greatly increased their productivity, and extended their semantic range (Růžička 1963, 370). Passive participles also came to play a larger predicative role in OCS than elsewhere in Slavic through direct Greek influence (Růžička 1963, 265; 369). Importantly for our discussion, but not surprisingly, the objective complement have constructions of the New Testament were also translated virtually word for word, not with an l-participle, but rather with a past passive participle, in direct imitation of the Greek original:

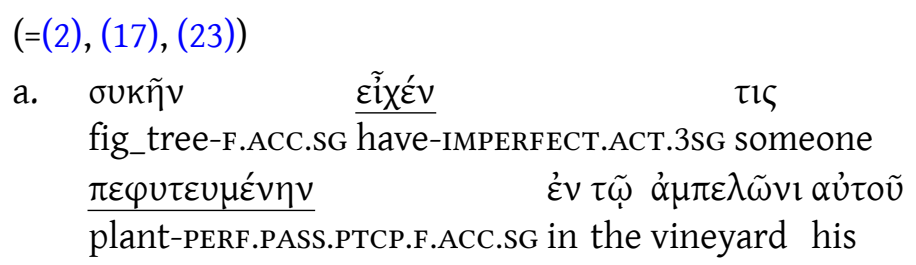

[37] This verse is not attested in Gothic.

[38] For example, in 1Corinthians 15:19, Gothic and Latin render the perfect participle of the Greek periphrastic be perfect as a present active participle, preserving the active voice but losing the reference to anteriority:

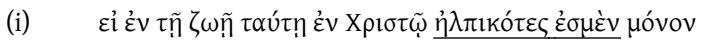
$[\mathrm{GK}]$ jabai in pizai libainai [ainai] in Xristau wenjandans sijum patainei [A] si in hac vita tantum in Christo sperantes sumus 
b. smokovinnico iměaše edinŭ vŭ vinogradě fig_tree-F.ACC.sG have-IMPERFECTIVE.ACT.3sg one in vineyard svoemı̆ vŭsaždeno

his plant-PAST.PASS.PTCP.F.ACC.SG

'A certain man had a fig tree planted in his vineyard' (Luke 13:6)

As we have seen with regard to Latin and Gothic, the OCS have constructions are better viewed as objective complement-type perfects than as fully grammaticalized perfects; accordingly, the have has more possessive semantic value than a pure auxiliary would. Related to this fact, it is significant that it is the be construction which takes hold in the East, as mentioned above, in traditions under the sway of Byzantine Greece, not the grammaticalized have construction. It is, in fact, this very tendency in the East to use the be-auxiliary to form the perfect vs. the propensity towards have/be in the West which has left its mark on the distribution of perfect auxiliaries in Europe today: as the map in figure 1 on page 68 indicates, the distribution appears to follow confessional lines fairly closely, with be-perfects occurring especially in languages influenced by Greek Orthodoxy, and have/be-perfects appearing predominantly in languages under the sway of Roman Catholicism. This role of religious affiliation as an essential force in the formation of the European perfect is explored in more detail in Drinka (Forthcoming).

\section{[6] CONCLUSION}

In conclusion, we have seen that the sacral stamp of Greek, and upon Greek, has operated on a large scale, as well as in the minute details. Greek has set the tone and provided the template. Translators have shaped their style and syntax according to these patterns, as they endowed their own words with the archaic sounds of the past that connoted reverence and membership in the Christian community. We have seen how this tradition of harkening back to ancient patterns has been documented even for the evangelists themselves, and above all for Luke.

With regard specifically to the periphrastic structures focused on in this paper, we have noted the increased productivity above all of the periphrastic progressive in NT Greek, based especially on the model of the Septuagint. This construction comes to be copied in the Vulgate, and is found especially in Latin writings which spring from the Christian tradition. Writings which were not connected to Christianity, even if they were influenced by Greek, did not participate in this trend. What we can conclude, with Amenta (2003), is that this structure had become a symbol of membership in the Christian community, and that the Vulgate itself served as a conduit of this structure into the European written tradition. The eager adoption of these structures in Gothic and Old Church Slavonic bears witness to the power of the "sacral stamp" of Greek.

The periphrastic perfect also grew in use, but less robustly; it apparently has no 


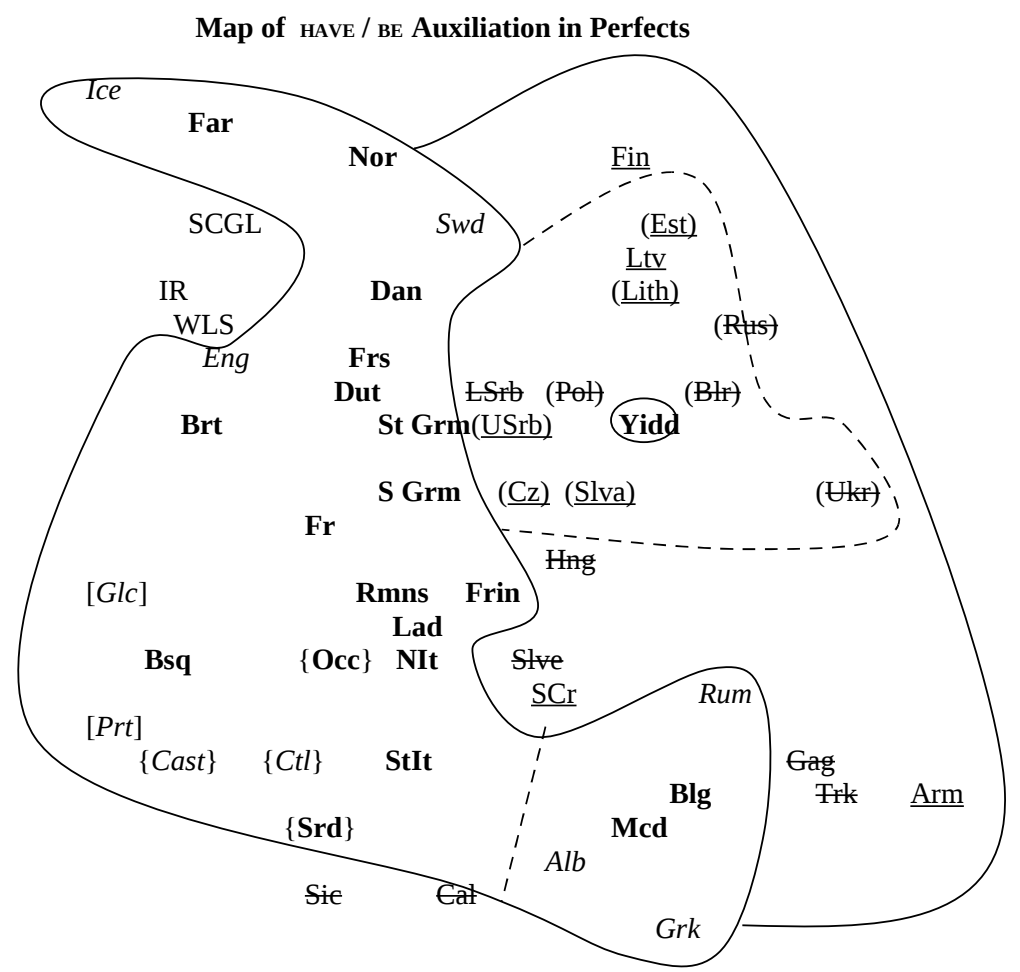

Bold

Underline $=$ BE only

Italics = HAVE only (excluding archaic Gk. Perf. in HAVE / BE in periphery)

(Parentheses) = historically BE, with some examples of have (esp. W.Slav., N.Rus dialects, etc.)

Erossent = Preterite greatly preferred over Perfect (Sic, Cal) or Periphrastic Perfect not found (Rus, Blr, Ukr, Pol, LSrb, Slve): old Be Perfs > Past (BE usually lost) ; likewise Hng. Trk: no Periphrastic Perfect per se, but categories which are closely related. Gag: no Perf, no aux's.

[Brackets] = tener used as aux.

$\{$ Curly brackets $\}=$ haver remains as aux., but main vb. $>$ tener

CAPS $\quad=\mathrm{BE}(+$ 'after' $)+$ verbal noun $(\mathrm{Ir}, \mathrm{Wls}, \mathrm{ScGl})$ 
predecessor in the LXX. The objective complement-style have perfect was imitated precisely in Latin, Gothic, and Old Church Slavonic, while the be perfect was only rendered literally in OCS, where past and perfect active participles were available, as in Greek.

Gothic provides essential evidence which can help us unravel the complex history of the perfect in Europe: as mentioned above, Gothic tends to imitate the less grammaticalized, objective-complement style of perfects of NT Greek, but in several cases where Latin influence is clearly in evidence, the use of the have perfect resembles the more grammaticalized version to be found in western Europe later. Gothic, then, may be providing evidence of two strata of influence, the earlier owing to the model of Greek, the later to the influence of Latin. This fact provides indirect but key evidence supporting the claim made by Meillet (1970) that Latin played an essential role in the development of the Germanic perfects.

In general, we can conclude that the influence of Greek on the syntactic and stylistic patterns which eventually developed in eastern and western Europe was substantial. The progressive, a clear mark of a "Christian accent", was directly copied in each of the traditions examined here; the perfect, on the other hand, was interpreted in western Europe through the lens of Latin.

\section{ACKNOWLEDGMENTS}

My sincere thanks to Steve Kellman and William Short for useful discussion and for advice on interpreting several Hebrew and Late Latin passages, respectively.

\section{PRIMARY SOURCES}

Arndt, W. \& B. Krusch (eds.). 1937-1951. Gregorii Turonensis opera. Pars I, Historia Francorum. Berlin.

Colunga, A. \& L. Turrado (eds.). 1946. Vulgata Clementina. Madrid: Biblioteca de Autores Christianos.

Jülicher, A. (ed.). 1963. Itala: Das Neue Testament in altlateinischer Überlieferung. Johannes Evangelium. Berlin-New York: Walter de Gruyter.

Jülicher, A. (ed.). 1970. Itala: Das Neue Testament in altlateinischer Überlieferung. Marcus Evangelium. Berlin-New York: Walter de Gruyter.

Jülicher, A. (ed.). 1972. Itala: Das Neue Testament in altlateinischer Überlieferung. Matthäus Evangelium. Berlin-New York: Walter de Gruyter.

Jülicher, A. (ed.). 1976. Itala: Das Neue Testament in altlateinischer Überlieferung. Lucas Evangelium. Berlin-New York: Walter de Gruyter. 
Merk, A. (ed.). 1992. Novum Testamentum graece et latine. 11th ed. Rome: Sumptibus Pontificii Instituti Biblici.

Migne, J.-P. (ed.). 1845. Patrologiae cursus completus. Series latina. Vol. 22. Paris: Migne.

Mommsen, Th. (ed.). 1882a. Jordanes. Getica: De origine actibusque Gothorum. Berlin: Weidmann.

Mommsen, Th. (ed.). 1882b. Jordanes. Romana: De origine actibusque gentis Romanorum. Berlin: Weidmann.

Oder, E. (ed.). 1901. Claudii Hermeri, Mulomedicina Chironis. Leipzig: Teubner.

Rahlfs, A. (ed.). 1971. Septuaginta. 9th ed. Stuttgart: Württembergische Bibelanstalt.

Robinson, M. \& W. Pierpont (eds.). 2000. The Greek New Testament according to the Byzantine textform. Southborough, MA: Chilton Book Publishing.

Streitberg, W. (ed.). 1971. Die gotische Bibel. 6th ed. Heidelberg: Carl Winter.

Ugenti, V. (ed.). 1980. Luciferi Calaritani. De regibus apostaticis et moriendum esse pro Dei filio. Lecce: Edizioni Milella.

WORKS CITED

Adams, J. N., Mark Janse \& Simon Swain (eds.). 2002. Bilingualism in ancient society: Language contact and the written text. Oxford-New York: Oxford University Press.

Aerts, Willem. 1967. Periphrastica. Chicago: Argonaut.

Aland, K. (ed.). 1972. Die alten Übersetzungen des Neuen Testaments, die Kirchenväterzitate und Lektionare. Berlin-New York: Walter de Gruyter.

Amenta, Luisa. 2003. Perifrasi aspettuali in greco e in latino: origini e grammaticalizzazioni. Milano: Francoangeli.

Aranovich, Raúl (ed.). 2007. Split auxiliary systems: a cross-linguistic perspective. Amsterdam: John Benjamins.

Asenova, Petja. 1999. Bulgarian. In Hinrichs (1999) 211-37.

Banfi, Emanuele. 1985. Linguistica balcanica. Bologna: Zanichelli.

Benveniste, Emile. 1971. The linguistic functions of 'to be' and 'to have'. In Problems in general linguistics, 163-79. Coral Gables, FL: University of Miami Press. (Translation of Problèmes de linguistique générale. Editions Gallimard). 
Burkitt, Francis. 1900. The Vulgate Gospels and the Codex Brixianus. Journal of Theological Studies I. 129-35.

Burton, Philip. 2002. Assessing Latin-Gothic interaction. In Adams et al. (2002) 393-418.

Ceglia, G. 1998. L'evoluzione della costruzione perifrastica verbale nel greco del nuovo testamento. Archivio Glottologico Italiano 83. 20-44.

Drinka, Bridget. 2003. Areal factors in the development of the European periphrastic perfect. Word 54(1). 1-38.

Drinka, Bridget. 2007. The development of the have perfect: Mutual influences of Greek and Latin. In Aranovich (2007) 101-121.

Drinka, Bridget. Forthcoming. Language contact in Europe: The periphrastic perfect through history. Cambridge: Cambridge University Press.

Friedrichsen, G. W. S. 1926. The Gothic version of the Gospels: A study of its style and textual history. London: Oxford University Press.

Friedrichsen, G. W. S. 1939. The Gothic version of the Epistles: A study of its style and textual history. London: Oxford University Press.

Hannick, Christian. 1972. Das Neue Testament in altkirchenslavischer Sprache. In Aland (1972) 403-435.

Herman, József. 1997. Vulgar Latin. University Park, Pennsylvania: Pennsylvania State University Press.

Hinrichs, Uwe (ed.). 1999. Handbuch der Südosteuropa-linguistik. Wiesbaden: Harrassowitz.

Horrocks, Geoffrey. 1997. Greek: A history of the language and its speakers. London-New York: Longman.

Hunter, M. J. 1969. The Gothic Bible. In Lampe (1969) 338-62.

Kauffmann, F. 1900. Beiträge zur Quellenkritik der gotischen Bibelübersetzung. 5. Der Codex Brixianus. Zeitschrift für Deutsche Philologie 30. 145-83.

Klein, Jared S. 1992. On the independence of Gothic syntax, I: Interrogativity, complex sentence types, tense, mood, and diathesis. Journal of Indo-European Studies 20. 339-379.

Krause, Wolfgang. 1968. Handbuch des Gotischen. München: Beck. 
Lampe, G. W. H. (ed.). 1969. The Cambridge history of the Bible. Vol II: The West from the Fathers to the Reformation. Cambridge: Cambridge University Press.

Lehmann, Winfred P. (ed.). 1986. A Gothic etymological dictionary. Leiden: Brill.

Lehmann, Winfred P., Esther Raizen \& Helen-Jo Jakusz Hewitt. 1999. Biblical Hebrew: An analytic introduction. San Antonio: Wings Press.

Lloyd, Albert. 1979. Anatomy of the verb. The Gothic verb as a model for a unified theory of aspect, actional types and verbal velocity. Amsterdam: John Benjamins.

Loewe, Raphael. 1969. The medieval history of the Latin Vulgate. In Lampe (1969) 102-154.

Meillet, Antoine. 1922. Des innovations du verbe slave. Revue des études slaves 2. 38-46.

Meillet, Antoine. 1970. General characteristics of the Germanic languages. Coral Gables, FL: University of Miami Press. (Translation by William Dismukes of Caractères généraux des langues germaniques. 1930. 4th ed. Paris: Klincksieck).

Metzger, Bruce. 1977. The early versions of the New Testament: Their origin, transmission, and limitations. Oxford: Clarendon Press.

Moulton, James \& Wilbert Howard. 1920. A grammar of New Testament Greek. Vol. II. Accidence and word formation. Edinburgh: T \& T Clark.

Psaltes, Stamatios B. 1913. Grammatik der byzantinischen Chroniken. Göttingen: Vandenhoeck \& Ruprecht.

Růžička, Rudolf. 1963. Das syntaktische System der altslavischen Partizipien und sein Verhältnis zum Griechischen. Berlin: Akademie Verlag.

Schaller, Helmut W. 1975. Die Balkansprachen. Heidelberg: Carl Winter.

Scherer, Philip. 1954. Aspect in Gothic. Language 30. 211-223.

Stutz, Elfriede. 1972. Das Neue Testament in gotischer Sprache. In Aland (1972) 376-402.

Sutcliffe, E. F. 1969. Jerome. In Lampe (1969) 80-101.

Trost, Klaus. 1972. Perfekt und Konditional im Altkirchenslavischen. Wiesbaden: Harrassowitz.

Tzitzilis, Christos. 1999. Der Einfluß des Griechischen in Südosteuropa. In Hinrichs (1999) 585-617. 
Večerka, Radoslav. 1993. Altkirchenslavische (altbulgarische) Syntax. II. Die innere Satzstruktur. Freiburg i. Br.: U. W. Weiher.

Wifstrand, Albert. 2005. Luke and the Septuagint. In Epochs and styles: Selected writing on the New Testament Greek language, and Greek culture in the post-classical era, Tübingen: Mohr Siebeck. (Originally published in Swedish as 'Lukas och Septuaginta', Svensk Teologisk Kvartalskrift 16 (1940): 243-262).

AUTHOR CONTACT INFORMATION

Bridget Drinka

Department of English

University of Texas at San Antonio

One UTSA Circle

San Antonio, TX 78249

USA

bridget.drinka@utsa.edu 